\title{
Omentin rs2274907 gene polymorphism and the risk of metabolic syndrome: a preliminary report
}

\section{Polimorfizm genu omentyny rs2274907 a ryzyko wystąpienia zespołu metabolicznego - badania wstępne}

\author{
Edyta Suliga, Dorota Kozieł², Elżbieta Cieśla³, Dorota Rębak², Monika Wawszczak4, \\ Wioletta Adamus-Białek ${ }^{4}$, Edyta Naszydłowska5 , Agnieszka Piechowska ${ }^{4}$, Stanisław Głuszek2,6 \\ ${ }^{1}$ Department of Nutrition and Dietetics, Institute of Public Health, Faculty of Medicine and Health Sciences, Jan Kochanowski \\ University, Kielce, Poland \\ Head of the Department: Prof. JKU Edyta Suliga \\ ${ }^{2}$ Department of Surgery and Surgical Nursing with the Scientific Research Laboratory, Institute of Medical Sciences, Jan Kochanowski \\ University, Kielce, Poland \\ Head of the Department: Prof. Stanisław Głuszek MD, PhD \\ ${ }^{3}$ Department of Developmental-Age Research, Institute of Public Health, Faculty of Medicine and Health Sciences, Jan Kochanowski \\ University, Kielce, Poland \\ Head of the Department: Prof. JKU Grażyna Nowak-Starz \\ ${ }^{4}$ Genetic Laboratory, Institute of Medical Sciences, Faculty of Medicine and Health Sciences, Jan Kochanowski University, Kielce, Poland \\ Head of the Laboratory: Wioletta Adamus-Białek PhD \\ ${ }^{5}$ Department of Social Prevention, Institute of Public Health, Faculty of Medicine and Health Sciences, Jan Kochanowski University, \\ Kielce, Poland \\ Head of the Department: Prof. JKU Monika Szpringe \\ ${ }^{6}$ Department of Clinic General Oncological and Endocrinological Surgery, Regional Hospital, Kielce, Poland \\ Head of the Department: Prof. Stanisław Głuszek MD, PhD
}

Key words: omentin rs2274907, adipokines, polymorphism, metabolic syndrome.

Słowa kluczowe: omentyna rs2274907, adipokiny, polimorfizm, zespół metaboliczny.

\begin{abstract}
Introduction: Omentin is a relatively recently examined adipokine that appears to be associated with metabolic risk factors and metabolic syndrome.

Aim of the research: To analyse the relationship between omentin rs2274907 gene polymorphism and the risk of metabolic syndrome and its components.

Material and methods: Genetic material and the clinical data of 219 individuals were analysed, including 108 with metabolic syndrome (MetS), diagnosed on the basis of International Diabetes Federation (IDF) criteria. Omentin rs2274907 mutation was detected using the PCR-RFLP method.

Results: The genotype distribution showed no deviation from the Hardy-Weinberg equilibrium $\left(\chi^{2}=3.055 ; p=0.080\right)$. No significant association was found between the Asp allele of omentin rs2274907 and MetS or its components, when compared to the Val allele $(p=0.198)$. The Val/Asp, Asp/Asp and Val/Asp + Asp/Asp genotypes also showed no association with MetS and its components when compared to Val/Val genotype ( $p=0.662 ; p=0.627 ; p=0.938$, respectively). Only a statistically insignificant tendency towards a more frequent occurrence of the Val/Asp genotype in subjects with MetS (42.60\% vs. $34.24 \%)$ and more frequent occurrence of the Asp/Asp genotype in the control group (53.15\% vs. 44.44\%) was reported. Statistically significant correlations between omentin Val109Asp polymorphism and MetS risk and its components were not found in the model adjusted for age, sex, smoking habits or physical activity.

Conclusions: The results of the conducted research did not show any significant relationship between omentin polymorphism Val109Asp and MetS risk. There were no associations of this polymorphism with any of the MetS components. It is necessary to conduct further research on a larger population.
\end{abstract}

\section{Streszczenie}

Wprowadzenie: Omentyna to jedna ze stosunkowo niedawno opisanych adipokin. Wydaje się, że ma ona związek z metabolicznymi czynnikami ryzyka i zespołem metabolicznym.

Cel pracy: Analiza zależności pomiędzy polimorfizmem genu omentyny rs2274907 a ryzykiem wystąpienia zespołu metabolicznego (MetS) oraz jego elementów. 
Materiał i metody: Analizie poddano materiał genetyczny i dane kliniczne 219 wolontariuszy, w tym 108 z MetS rozpoznanym na podstawie kryteriów International Diabetes Federation (IDF). Analizę mutacji rs2274907 omentyny przeprowadzono metoda PCR-RFLP.

Wyniki: Rozkład genotypów w badanej grupie nie odbiegał od rozkładu określonego według równania Hardy’ego-Weinberga $\left(\chi^{2}=3,055 ; p=0,080\right)$. Nie stwierdzono statystycznie istotnej zależności pomiędzy występowaniem allela Asp (rs2274907) omentyny a ryzykiem występowania MetS lub któregokolwiek z jego komponentów w porównaniu z allelem Val (rs2274907) $(p=0,198)$. Nie wykazano również zależności pomiędzy ryzykiem wystąpienia MetS lub któregokolwiek z jego składowych a genotypem Val/Asp, Asp/Asp i Val/Asp + Asp/Asp w porównaniu z genotypem Val/Val ( $p=0,662 ; p=0,627 ; p=0,938$ ). Zanotowano jedynie nieistotną statystycznie tendencję do częstszego występowania genotypu Val/Asp u osobników z MetS (42,60\% vs 34,24\%) i częstszego występowania genotypu Asp/Asp u pacjentów z grupy kontrolnej (53,15\% vs 44,44\%). Nie stwierdzono istotnych statystycznie zależności między polimorfizmem omentyny Val109Asp a ryzykiem wystąpienia MetS oraz jego komponentów także w modelu adiustowanym ze względu na wiek, płeć, palenie oraz aktywność fizyczną.

Wnioski: Wyniki przeprowadzonych badań nie wykazały istotnych powiązań między polimorfizmem omentyny Val109Asp (rs2274907) a ryzykiem wystąpienia MetS. Nie stwierdzono również powiązań tego polimorfizmu z żadnym z komponentów MetS. Konieczne jest przeprowadzenie dalszych badań w tym zakresie w większej grupie pacjentów.

\section{Introduction}

The adipose tissue cells are capable of synthesising and secreting biologically active substances, called adipokines [1]. They fulfil various biological functions, including the regulation of appetite and satiety, maintaining energy homeostasis, fat and carbohydrate metabolism, insulin sensitivity, regulation of vascular haemostasis, blood pressure, and inflammatory and immunological processes [2]. Omentin is a relatively recently described adipokine that appears to be associated with metabolic risk factors, but its role in the organism is not yet fully understood.

Omentin is mainly produced in the visceral adipose tissue [3, 4]. It occurs in the form of two isoforms ( 1 and 2 ). The genes of both isoforms of omentin are located side by side in the chromosomal region 1q22q23, coupled with the prevalence of type 2 diabetes. De Souza Batista et al. [5] showed that the main isoform detected in human plasma is omentin-1. It was found that omentin stimulates the phosphorylation of the protein kinase B (Akt), and thereby enhances insulin signal transduction and increases the insulininduced uptake of glucose by adipose tissue [4-6]. These actions therefore suggest that it should increase insulin sensitivity. Studies have shown that omentin-1 concentration in serum is lower in obese than in lean individuals and is negatively correlated with body mass index (BMI), waist circumference, fat mass and visceral fat, serum concentration of leptin and insulin, insulin resistance indexes (HOMA-IR), and dyslipidaemia. It is, however, positively correlated with serum adiponectin and high-density lipoprotein (HDL)-cholesterol levels [5, 7-9].

Wittenbecher et al., despite inverse associations of omentin-1 levels with measures of body fat, found no indication of a diabetes protective role of omentin-1 in prospective analyses [10].

The studies so far on the relationship between the serum concentration of omentin and metabolic syndrome (MetS) distribution have produced inconclusive results. Analyses carried out by Jialal et al. confirmed that plasma levels of omentin were $41 \%$ lower in patients with nascent metabolic syndrome compared with the control group [11]. Also, in obese teenagers, serum omentin levels were significantly lower in the MetS group compared to the group without MetS [12]. Vu et al. found that plasma omentin concentrations did not differ significantly between individuals with and without MetS [13]. However, men with metabolic syndrome had significantly lower omentin levels than men without MetS. In research conducted by Kilic et al. the plasma omentin concentration was similar in non-diabetic MetS patients and the healthy control group [14].

In some papers, it has been shown that the expression of the omentin gene decreases in obese patients with type 2 diabetes $[5,15]$ and in patients with coronary artery disease [16]. In the Caucasian population, however, no relationship was found between the mutations of the omentin gene and the occurrence of type 2 diabetes [17]. In the Kyrgyz population, however, it was noted that the genotype Val109Val in the omentin gene increased the risk of abdominal obesity - one of the MetS components [18]. In the available literature, no work has been published so far on the relationship between polymorphisms of the omentin gene and MetS.

\section{Aim of the research}

Therefore, the aim of this work was to analyse the relationship between omentin rs2274907 gene polymorphism and the risk of MetS and its components.

\section{Material and methods}

\section{Study population}

Genomic DNA isolated from 219 participants of the PONS study and their clinical data were used in this study. All participants belonged to the Caucasian population. Detailed information regarding the project and research procedures have been described in previously published papers [19, 20]. In 108 individu- 
als, MetS was diagnosed on the basis of International Diabetes Federation (IDF) criteria [21], the remaining 111 participants were a control group. Three abnormal findings out of the following five qualified a person for metabolic syndrome: waist circumference $\geq 94 \mathrm{~cm}$ in males and $\geq 80 \mathrm{~cm}$ in females; triglycerides $\geq 150 \mathrm{mg} / \mathrm{dl}(1.7 \mathrm{mmol} / \mathrm{l})$ or drug treatment for elevated triglycerides, HDL cholesterol $<40 \mathrm{mg} / \mathrm{dl}$ $(1.0 \mathrm{mmol} / \mathrm{l})$ in males and $<50 \mathrm{mg} / \mathrm{dl}(1.3 \mathrm{mmol} / \mathrm{l})$ in females or drug treatment to reduce HDL cholesterol; fasting glucose $\geq 100 \mathrm{mg} / \mathrm{dl}(5.5 \mathrm{mmol} / \mathrm{l})$ or diabetes treatment; and systolic blood pressure $\geq 130 \mathrm{~mm} \mathrm{Hg}$ or diastolic blood pressure $\geq 85 \mathrm{~mm} \mathrm{Hg}$ or drug treatment for hypertension.

The study was approved by the Ethics Committee from the Cancer Centre and Institute of Oncology in Warsaw (data collection) and by the Committee on Bioethics at the Faculty of Health Sciences, Jan Kochanowski University in Kielce, Poland (data analysis) (No. 45/2016).

\section{Genotyping}

Omentin rs2274907 mutation was detected using the PCR-RFLP method according to the protocol described by Schäffler et al. The primers OmtF (5' GAGCCTTTAGGCCATGTCTCT 3') and OmtR (5' CTCTCСTTCTTCTCCAGCCCAT 3') were used to amplify the $471 \mathrm{bp}$ DNA of Omentin gene fragment [17]. PCR-based RFLP analysis was performed using commercial PCR premix DreamTaq ${ }^{\mathrm{TM}}$ Green DNA Polymerase Master Mix (2×) (Thermo Scientific ${ }^{\mathrm{TM}}$ ) according to the manufacturer's instructions - briefly: $1 \mu \mathrm{l}$ of template DNA ( $25 \mathrm{ng} / \mu \mathrm{l}), 1 \mu \mathrm{l}$ of each primer $(10 \mathrm{pmol} / \mu \mathrm{l})$, DNase-free water to filled up to $25 \mu \mathrm{l}$ of total volume. The amplification conditions were as follows: denaturation at $95^{\circ} \mathrm{C}$ for $3 \mathrm{~min}$, followed by amplification for 30 cycles of $95^{\circ} \mathrm{C}$ for $1 \mathrm{~min}, 56^{\circ} \mathrm{C}$ for $1 \mathrm{~min}$, and $72^{\circ} \mathrm{C}$ for $1 \mathrm{~min}$, followed by a final extension at $72^{\circ} \mathrm{C}$ for $8 \mathrm{~min}$. Amplified PCR products were visualised under the gel documentation system. Next, the PCR products were digested at $37^{\circ} \mathrm{C}$ by the restriction enzyme AccI (Thermo Scientific ${ }^{\mathrm{TM}}$ ) according to the manufacturer's instructions and visualised under the gel documentation system.

The results of restriction were interpreted on the agarose gel electrophoresis, two bands (274 bp and $197 \mathrm{bp}$ ) were specific for Val/Val homozygotes, three bands (471 bp, $274 \mathrm{bp}$ and $197 \mathrm{bp}$ ) were specific for Val/Asp heterozygotes, and one single band of $471 \mathrm{bp}$ represent wild type Asp/Asp homozygotes (Figure 1).

\section{Anthropometric and laboratory measurements}

Height was measured using a stadiometer, with an accuracy of $0.1 \mathrm{~cm}$. Weight was obtained by using a body composition analyser (Tanita SC 240MA),

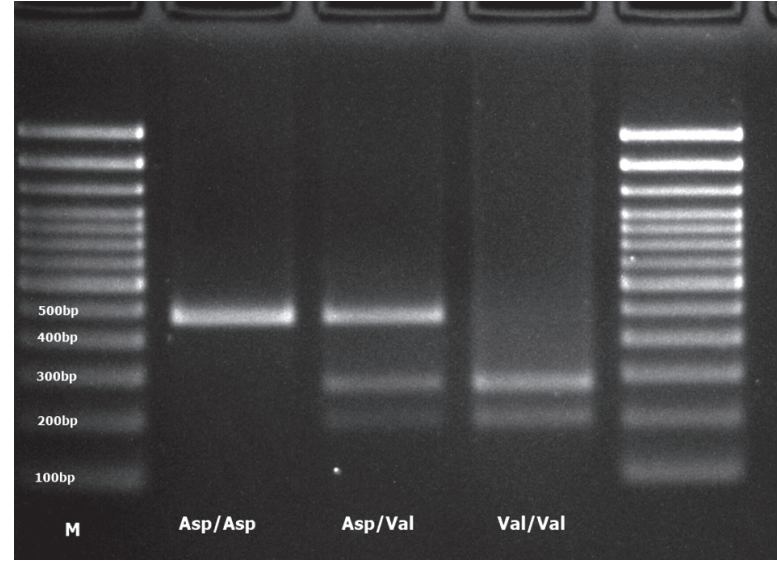

Figure 1. Electrophoresis band patterns of PCR-based RFLP analysis of the Val109Asp SNP. The product sizes were $471 \mathrm{bp}$ for A allele (Asp), $274 \mathrm{bp}$ and 174 bp for T allele (Val) M-DNA marker.

with an accuracy of $0.1 \mathrm{~kg}$. These measurements were used to calculate BMI $\left(\mathrm{kg} / \mathrm{m}^{2}\right)$. Waist circumference was measured halfway between the lower rib edge and the upper iliac crest using a metric measure with an accuracy of $0.1 \mathrm{~cm}$. Blood pressure was measured on the artery of the right upper limb when the participant was seated, using an Omron blood pressure monitor (Model M3 Intellisense). An average of two measurements were used for analysis. The glucose concentration in the blood serum was measured using the enzyme method with hexokinase, while the concentration of triglycerides (TG) was assessed using the phosphoglyceride oxidase-peroxidase method. The concentration of HDL-cholesterol was measured using the colorimetric non-precipitation method.

\section{Demographic variables and lifestyle data}

The demographic variables included: gender (men, women) and age (37-51, 52-66 years old). The respondents who smoked cigarettes on a daily basis during the study were classified as current smokers, while those who had not smoked for longer than 6 months were classified as former smokers. The rest were regarded as non-smokers. Physical activity (PA) was evaluated with the use of the International Physical Activity Questionnaire (IPAQ) - the long form [22] and expressed in minutes/day.

\section{Statistical analysis}

All data were processed using the Statistical Package Statistica software (version for Windows 13.1 TIBCO Software Inc. - StatSoft, Poland). All continuous variables were expressed as means $(x) \pm$ standard deviations (SD) or medians (Me) and interquartile ranges (Q1-Q3), and all categorical variables were reported as frequency and percentage. Differences in 
baseline characteristics between MetS patients and the control group were assessed through the U MannWhitney-test and the $\chi^{2}$ test. Genotype and allele frequencies were analysed with the $\chi^{2}$ test. Additionally, the $\chi^{2}$ test was used to determine whether the genotype distribution was consistent with Hardy-Weinberg equilibrium expectations. Multivariate logistic regression analyses were used to estimate the odds ratios (ORs) and 95\% confidence intervals (CI) for MetS, abdominal obesity, elevated blood pressure, increased glucose, triglycerides, and decreased HDL-cholesterol concentration. In the analysis, allel Val (or genotype $\mathrm{Val} / \mathrm{Val}$ ) was adopted as reference. In the second model, the risk of MetS and its components was adjusted for gender, age, smoking and total PA. A $p$-value $<0.05$ was considered statistically significant.

\section{Results}

A total of 108 subjects with a diagnosis of MetS and 111 individuals representing the control group participated in the study. Table 1 shows the demographic and biochemical characteristics of the study participants. The group with MetS was similar to the control group in terms of sex, age, and the percentage of smokers. However, they were characterised by a significantly shorter time of total physical activity during the day $(p=0.039)$. Moreover, in overweight participants (BMI $\geq 25.0 \mathrm{~m} / \mathrm{kg}^{2}$ ), abdominal obesity, elevated blood pressure, glucose concentration, triglycerides, and decreased HDL-cholesterol concentration were more prevalent than in those in the control group (all $p<0.001$ ). The distribution of genotypes of omentin rs2274907 polymorphism did not differ significantly between the control group and the participants with MetS (Table 2).
However, there was a trend towards a slightly more frequent occurrence of the Val/Asp genotype in individuals with MetS in comparison to the control group (42.60\% vs. $34.24 \%$ ) and a higher frequency of Asp/Asp genotype in the control group (53.15\% vs. $44.44 \%$ ) in comparison to the group with MetS. The genotype distribution showed no deviation from the Hardy-Weinberg equilibrium in the whole study sample $\left(\chi^{2}=3.055 ; p=0.080\right)$, in subjects with MetS $\left(\chi^{2}=0.320 ; p=0.572\right)$, and in control subjects $\left(\chi^{2}=3.623\right.$; $\left.p=0.057\right)$. The minor allele frequency (MAF) (Val allele) of omentin rs2274907 polymorphism was 0.320 in total, 0.343 in MetS, and 0.297 in control subjects.

Table 3 shows no significant association between the Asp/Asp genotype of omentin rs2274907 and MetS when compared to the other genotypes $(p=0.198)$. The Val/Asp, Asp/Asp, and Val/Asp + Asp/Asp genotypes also showed no association with MetS when compared to the Val/Val genotype ( $p=0.662 ; p=0.627$; $p=0.938$, respectively). The results of the conducted research showed that omentin Val109Asp polymorphism was not significantly related to any of the MetS components. In the model adjusted for age, sex, smoking, and total PA, there were no significant relationships between omentin Val109Asp polymorphism and the risk of MetS and its components (Table 4).

\section{Discussion}

Our study represents the first investigation of the possible association between omentin-1 rs2274907 polymorphism and the risk of metabolic syndrome. MetS is the accumulation of risk factors such as: abdominal obesity, dyslipidaemia, abnormal glycaemia, and elevated blood pressure $[21,23]$.

Table 1. General and biochemical characteristics of the study population

\begin{tabular}{|c|c|c|c|c|}
\hline Variables & Control $(n=111)$ & MetS $(n=108)$ & Statistical test & $P$-value \\
\hline Gender: women & $59(53.15 \%)$ & $53(49.07 \%)$ & $0.364^{a}$ & 0.546 \\
\hline Age: $52-66$ & $69(62.16 \%)$ & $80(74.07 \%)$ & $3.571^{\mathrm{a}}$ & 0.059 \\
\hline Current smokers & $20(18.02 \%)$ & $13(12.04 \%)$ & \multirow[t]{2}{*}{$1.567^{\mathrm{a}}$} & \multirow[t]{2}{*}{0.456} \\
\hline Former smokers & $38(34.23 \%)$ & $41(37.96 \%)$ & & \\
\hline $\begin{array}{l}\text { Total physical activity (PA), } \\
x \pm \text { SD; Me (Q1-Q3) [min/day] }\end{array}$ & $\begin{array}{c}270.60 \pm 145.59 \\
250.0(165.0-355.0)\end{array}$ & $\begin{array}{c}232.17 \pm 144.43 \\
210.0(135.0-320.0)\end{array}$ & $2.069^{b}$ & $0.039^{*}$ \\
\hline Overweight (BMI $\geq 25.0 \mathrm{~m} / \mathrm{kg}^{2}$ ) & 70 (63.09\%) & $98(90.74 \%)$ & $23.473^{a}$ & $<0.001^{*}$ \\
\hline Abdominal obesity & $58(52.25 \%)$ & 97 (89.81\%) & $37.341^{\mathrm{a}}$ & $<0.001^{*}$ \\
\hline Elevated blood pressure & $68(61.26 \%)$ & $102(94.44 \%)$ & $34.704^{a}$ & $<0.001^{*}$ \\
\hline Increased glucose concentration & $14(12.61 \%)$ & $66(61.11 \%)$ & $55.532^{\mathrm{a}}$ & $<0.001^{*}$ \\
\hline $\begin{array}{l}\text { Decreased HDL-cholesterol } \\
\text { concentration }\end{array}$ & $4(3.60 \%)$ & $60(55.56 \%)$ & $71.430^{\mathrm{a}}$ & $<0.001^{*}$ \\
\hline Increased TG concentration & $8(7.21 \%)$ & $71(65.74 \%)$ & $81.329^{a}$ & $<0.001^{*}$ \\
\hline
\end{tabular}

${ }^{a} \chi^{2}, d f=1,{ }^{b} U-M a n n-W h i t n e y,{ }^{*}$ statistically significant results $(p<0.05)$. 
Table 2. Genotype distribution of omentin rs2274907 polymorphism in the control group and MetS patients

\begin{tabular}{|lccccc|}
\hline Genotypes & Total $(\boldsymbol{N}=219)$ & $\begin{array}{c}\text { Control }(\boldsymbol{N}=111) \\
n(\%)\end{array}$ & $\begin{array}{c}\text { MetS }(\boldsymbol{N}=108) \\
n(\%)\end{array}$ & $\chi^{2} ; \mathrm{d} f=2$ & $P$-value \\
Val/Val & $28(12.85)$ & $14(12.73)$ & $14(12.96)$ & 1.687 & 0.430 \\
Val/Asp & $84(38.53)$ & $38(34.55)$ & $46(42.60)$ & & \\
Asp/Asp & $106(48.62)$ & $58(52.72)$ & $48(44.44)$ & & 0.341 \\
Val & $140(32.11)$ & $66(30.00)$ & $74(34.26)$ & 0.910 & \\
Asp & $296(67.89)$ & $154(70.00)$ & $142(65.74)$ & & \\
\hline
\end{tabular}

Table 3. Associations between omentin rs2274907polymorphism and the risk of MetS and its components - unadjusted model $(\mathrm{OR}(95 \% \mathrm{Cl})$

\begin{tabular}{|c|c|c|c|c|c|c|c|c|}
\hline $\begin{array}{l}\text { Components } \\
\text { of MetS }\end{array}$ & $\begin{array}{c}\text { Asp/Asp } \\
\text { (Val/Val + } \\
\text { Val/Asp ref.) }\end{array}$ & $P$-value & $\begin{array}{c}\text { Val/Asp } \\
\text { (Val/Val ref.) }\end{array}$ & $P$-value & $\begin{array}{c}\text { Asp/Asp } \\
\text { (Val/Val ref.) }\end{array}$ & $P$-value & $\begin{array}{c}\text { Val/Asp + } \\
\text { Asp/Asp } \\
\text { (Val/Val ref.) }\end{array}$ & $P$-value \\
\hline MetS & $\begin{array}{c}0.70 \\
(0.41-1.20)\end{array}$ & 0.198 & $\begin{array}{c}1.21 \\
(0.51-2.85)\end{array}$ & 0.662 & $\begin{array}{c}0.81 \\
(0.35-1.87)\end{array}$ & 0.627 & $\begin{array}{c}0.97 \\
(0.44-2.14)\end{array}$ & 0.938 \\
\hline $\begin{array}{l}\text { Abdominal } \\
\text { obesity }\end{array}$ & $\begin{array}{c}0.72 \\
(0.40-1.29)\end{array}$ & 0.268 & $\begin{array}{c}1.20 \\
(0.46-3.12)\end{array}$ & 0.709 & $\begin{array}{c}0.82 \\
(0.33-2.05)\end{array}$ & 0.676 & $\begin{array}{c}0.96 \\
(0.40-2.32)\end{array}$ & 0.935 \\
\hline $\begin{array}{l}\text { Elevated blood } \\
\text { pressure }\end{array}$ & $\begin{array}{c}0.89 \\
(0.47-1.69)\end{array}$ & 0.731 & $\begin{array}{c}1.00 \\
(0.35-2.84)\end{array}$ & 1.000 & $\begin{array}{c}0.89 \\
(0.33-2.45)\end{array}$ & 0.828 & $\begin{array}{c}0.94 \\
(0.36-2.46)\end{array}$ & 0.898 \\
\hline $\begin{array}{l}\text { Increased } \\
\text { glucose } \\
\text { concentration }\end{array}$ & $\begin{array}{c}1.07 \\
(0.62-1.86)\end{array}$ & 0.798 & $\begin{array}{c}0.66 \\
(0.28-1.60)\end{array}$ & 0.364 & $\begin{array}{c}0.80 \\
(0.34-1.85)\end{array}$ & 0.600 & $\begin{array}{c}0.74 \\
(0.33-1.65)\end{array}$ & 0.458 \\
\hline $\begin{array}{l}\text { Decreased } \\
\text { HDL-cholesterol } \\
\text { concentration }\end{array}$ & $\begin{array}{c}0.82 \\
(0.46-1.47)\end{array}$ & 0.500 & $\begin{array}{c}0.76 \\
(0.31-1.88)\end{array}$ & 0.557 & $\begin{array}{c}0.67 \\
(0.28-1.62)\end{array}$ & 0.372 & $\begin{array}{c}0.71 \\
(0.31-1.63)\end{array}$ & 0.420 \\
\hline $\begin{array}{l}\text { Increased TG } \\
\text { concentration }\end{array}$ & $\begin{array}{c}0.81 \\
(0.47-1.41)\end{array}$ & 0.465 & $\begin{array}{c}0.95 \\
(0.40-2.29)\end{array}$ & 0.911 & $\begin{array}{c}0.78 \\
(0.33-1.85)\end{array}$ & 0.577 & $\begin{array}{c}0.85 \\
(0.39-1.93)\end{array}$ & 0.705 \\
\hline
\end{tabular}

Table 4. Associations between omentin rs2274907polymorphism and the risk of MetS and its components - model adjusted for gender, age, smoking, and PA (OR (95\% CI))

\begin{tabular}{|c|c|c|c|c|c|c|c|c|}
\hline $\begin{array}{l}\text { Components } \\
\text { of MetS }\end{array}$ & $\begin{array}{c}\text { Asp/Asp } \\
\text { (Val/Val + } \\
\text { Val/Asp ref.) }\end{array}$ & $P$-value & $\begin{array}{c}\text { Val/Asp } \\
\text { (Val/Val ref.) }\end{array}$ & $P$-value & $\begin{array}{c}\text { Asp/Asp } \\
\text { (Val/Val ref.) }\end{array}$ & $P$-value & $\begin{array}{c}\text { Val/Asp + } \\
\text { Asp/Asp } \\
\text { (Val/Val ref.) }\end{array}$ & $P$-value \\
\hline MetS & $\begin{array}{c}0.69 \\
(0.40-1.20)\end{array}$ & 0.181 & $\begin{array}{c}1.26 \\
(0.52-3.09)\end{array}$ & 0.609 & $\begin{array}{c}0.77 \\
(0.33-1.80)\end{array}$ & 0.541 & $\begin{array}{c}0.98 \\
(0.44-2.21)\end{array}$ & 0.964 \\
\hline $\begin{array}{l}\text { Abdominal } \\
\text { obesity }\end{array}$ & $\begin{array}{c}0.65 \\
(0.35-1.20)\end{array}$ & 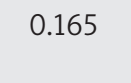 & $\begin{array}{c}1.22 \\
(0.44-3.39)\end{array}$ & 0 & $\begin{array}{c}0.70 \\
(0.26-1.85)\end{array}$ & 177 & $\begin{array}{c}0.90 \\
(0.36-2.72)\end{array}$ & 835 \\
\hline $\begin{array}{l}\text { Elevated blood } \\
\text { pressure }\end{array}$ & $\begin{array}{c}0.93 \\
(0.48-1.83)\end{array}$ & 841 & $\begin{array}{c}1.20 \\
(0.40-3.64)\end{array}$ & 0.746 & $\begin{array}{c}1.00 \\
(0.35-2.88)\end{array}$ & 0.998 & $\begin{array}{c}1.07 \\
(0.39-2.97)\end{array}$ & 0.888 \\
\hline $\begin{array}{l}\text { Increased glucose } \\
\text { concentration }\end{array}$ & $\begin{array}{c}1.21 \\
(0.68-2.15)\end{array}$ & 0.525 & $\begin{array}{c}0.66 \\
(0.26-1.71)\end{array}$ & 0.400 & $\begin{array}{c}0.91 \\
(0.38-2.17)\end{array}$ & 0.825 & $\begin{array}{c}0.82 \\
(0.35-1.89)\end{array}$ & 0.638 \\
\hline $\begin{array}{l}\text { Decreased } \\
\text { HDL-cholesterol } \\
\text { concentration }\end{array}$ & $\begin{array}{c}0.82 \\
(0.45-1.48)\end{array}$ & 05 & $\begin{array}{c}0.78 \\
(0.30-2.07)\end{array}$ & 0.625 & $\begin{array}{c}0.60 \\
(0.24-1.50)\end{array}$ & 0.277 & $\begin{array}{c}0.70 \\
(0.30-1.65)\end{array}$ & 0.413 \\
\hline $\begin{array}{l}\text { Increased TG } \\
\text { concentration }\end{array}$ & $\begin{array}{c}0.84 \\
(0.48-1.47)\end{array}$ & 0.540 & $\begin{array}{c}0.93 \\
(0.38-2.28)\end{array}$ & 0.870 & $\begin{array}{c}0.76 \\
(0.32-1.84)\end{array}$ & 0.546 & $\begin{array}{c}0.76 \\
(0.38-1.98)\end{array}$ & 0.730 \\
\hline
\end{tabular}


Papers in which the relationship between the concentration of omentine- 1 in serum and individual components of MetS were analysed gave inconclusive results. Moreno-Navarrete et al. showed that in obese individuals, serum omentin negatively correlated with waist circumference, fasting glucose, and triglycerides, but not with HDL [7]. On the other hand, after weight loss, there were no significant correlations between the concentration of omentin and metabolic risk factors. Auguet et al. found that the concentration of omentin in serum was inversely correlated only with fasting glucose, while it did not significantly correlate with other analysed components of MetS [8] Urbanová et al., however, did not find any significant dependency between the serum omentin- 1 and fasting glucose levels in both obese and type 2 diabetic patients in comparison to the control subjects [24]. The level of omentin was, however, related to the concentration of triglycerides and HDL-cholesterol. Herder et al. noted that in the group of individuals aged 62-81 years, higher serum levels of omentin-1 were associated with increases in fasting glucose and with incident type 2 diabetes [25]. Panagiotou et al. did not find any association of circulating omentin-1 with fasting glucose and blood pressure [26]. They observed only an association between serum omentin-1 and small VLDL particle size. $\mathrm{Vu}$ et al. found that plasma omentin-1 concentrations in men were correlated with the concentration of triglycerides and HDL-cholesterol but were not significantly correlated with any metabolic or clinical variables in women [13]. Cătoi et al. showed no significant association between serum omentin-1 and fasting glucose, triglycerides, and HDL-cholesterol in morbidly obese individuals [27]. However, after using multiple regression analysis they found an association between fasting glucose and circulating omentin-1 levels. Guvenc et al. did not find a correlation between serum omentin levels and components of MetS such as fasting glucose, HDL-cholesterol, and triglycerides in women with polycystic ovary syndrome [28]. Elsaid et al. showed that omentin-1 is inversely related to waist circumference and systolic blood pressure [29]. They did not notice, however, significant associations with glycaemic control and fasting lipids. The results of the analyses presented in the papers of various authors show that in many cases no significant relationships between serum omentin levels and individual MetS components were found.

The studies to date on the relationship between serum concentration of omentin and the dissemination of MetS as a syndrome have also produced inconclusive results. Shibata et al. demonstrate that plasma omentin levels inversely correlate with the number of metabolic risk factors such as dyslipidaemia, glucose intolerance, increased waist circumference, and high blood pressure [30]. A reduction of circulating levels of omentin significantly correlated with an increase in the mean number of metabolic risk factors. Analyses conducted by Jialal et al. demonstrated that plasma levels of omentin were $41 \%$ lower in patients with nascent metabolic syndrome compared with the control group [11]. In obese teenagers serum omentin-1 levels were significantly lower in the MetS group compared to the group without MetS $(289.5 \pm 51.9 \mathrm{ng} / \mathrm{ml}$ vs. $268.2 \pm 60 \mathrm{ng} / \mathrm{ml}$ ), although omentin did not show statistically significant correlations with abnormal glucose metabolism indicators [12]. Stejskal et al. found that omentin-1 serum levels were significantly lower in patients with premature coronary artery disease $(103.1 \pm 62.7 \mathrm{mg} / \mathrm{l})$ compared to MetS (668.2 $\pm 339.6 \mathrm{mg} / \mathrm{l})$ and healthy subjects $(623.0 \pm 373.5 \mathrm{mg} / \mathrm{l})$ $[31,32]$. The results of research conducted by Kilic et al. showed that although the plasma omentin-1 concentrations were correlated with high triglyceride and low HDL-C levels, which are two of the five metabolic syndrome indicators, the plasma omentin-1 concentrations are similar in MetS subjects and individuals in the healthy control group [14]. Vu et al. confirmed that plasma omentin levels did not differ significantly between individuals with and without MetS [13].

It is believed that MetS is the result of complex interactions between genetic and environmental factors. However, the precise determination of the genotype responsible for the development of MetS is quite difficult because it is a combination of the effects of more than one risk factor. The results of our analyses did not show any significant relationship between omentine-1 polymorphism Val109Asp and MetS risk. We have not found any connections of this polymorphism with any of the MetS components. There was only a tendency for the more frequent occurrence of the Val/Asp genotype in individuals with MetS (42.60\% vs. $34.24 \%$ in the control group) and the higher frequency of Asp/Asp genotype in the control group (53.15\% vs. $44.44 \%$ in the MetS group), which, however, did not reach the level of statistical significance.

Studies on the expression and polymorphisms of omentin genes in relation to metabolic risk factors are among the few. In the available literature, the relationship between omentin gene polymorphisms and MetS risk as a syndrome has not been analysed so far [32]. The influence of omentin polymorphism on MetS and its components can therefore only be concluded indirectly, analysing the association of this polymorphism with the prevalence of other diseases such as obesity, as well as type 2 diabetes, non-alcoholic fatty liver disease (NAFLD), and coronary artery disease (CAD), for which MetS is a risk factor. In some studies, it has been shown that the expression of the omentin gene decreases in obese people, patients with type 2 diabetes $[5,15]$ and in patients with CAD [16]. Urbanová et al. noted that omentin mRNA expression in subcutaneous adipose tissue did not correlate with any of anthropometric and biochemical parameters 
studied, although serum omentin concentrations negatively correlated with BMI, LDL-cholesterol, triglycerides, insulin, and leptin levels and were positively related to serum HDL-cholesterol [24].

Splichal et al. found that the carriers of the Val allele, despite the lack of significant differences in BMI and body fat percentage, reach the threshold of obesity with lower energy consumption than the carriers of the Asp allele [33]. This may indicate the existence of a potential, more "thrifty" phenotype in these people. In the Kyrgyz population, it was confirmed that the genotype Val109Val in omentin gene increased the risk of abdominal obesity - one of the MetS components [18]. The results of our research are to some extent consistent with the results of the papers cited above, because in the adjusted model, carriers of the Asp allele (as compared to the carriers of the Val allele) showed quite a clear, though statistically insignificant, tendency to a lower risk of abdominal obesity $(\mathrm{OR}=0.65 ; p=0.169)$ and MetS $(\mathrm{OR}=0.69 ; p=0.181)$ In another study conducted in the Caucasian population, however, no association was found between the mutations of the omentin gene and the occurrence of type 2 diabetes [17]. Kohan et al. noted that the frequency of omentin-1 rs2274907 genotypes in patients with NAFLD was significantly different from those in the control subjects [34]. They concluded that omentin-1 rs2274907 polymorphism might be a candidate genetic factor for susceptibility to NAFLD. Studies on the relationship between omentin polymorphisms and the occurrence of CAD, for which MetS is a risk factor, gave inconclusive results. In the Pakistani population, it has been demonstrated that the heterozygous Val/Asp genotype of omentin-1 gene is more associated with the risk of developing CAD, while the homozygous genotype Asp/Asp reduces the risk of developing CAD [35]. A similar, although statistically insignificant tendency, was noted in the results of our research. The odds ratio (OR) in the adjusted model showed a higher MetS risk in subjects with the $\mathrm{Val} /$ Asp genotype $(\mathrm{OR}=1.26, p=0.609)$ and a lower risk of decreased HDL cholesterol concentration in individuals with the Asp/Asp genotype $(\mathrm{OR}=0.60$; $p=0.277$ ) (compared to the Val/Val genotype). Yörük et al. did not find a significant relationship between the omentin-1 gene Val109Art polymorphism and CAD in the Turkish population; however, it was observed that the Val/Val heterozygous genotype was more frequent in CAD subjects [36]. Jamshidi et al. also did not find a significant relationship between Val109Asp polymorphism and the risk of CAD [37] When the analysis was carried out separately according to sex, there was a significant difference in the distribution of alleles in men but not in women. Studies on the influence of the omentin-1 gene Val109Asp polymorphism on metabolic risk factors and diseases for which MetS is a risk factor have not yet yielded conclusive results and require further analysis. As suggested by Schäffler et al., one should also take into account the possibility that the polymorphism Val109Asp in the human gene encoding omentin is more of a single nucleotide polymorphism than a real disease-causing mutation [17].

The main limitation of the study is the small number of participants, while the main strength is the inclusion (in the statistical analysis) of confounding factors that can modify the risk of MetS and its components.

\section{Conclusions}

The results of the study did not show any significant association between omentine-1 polymorphism Val109Asp and MetS risk. There were no associations of this polymorphism with any of the MetS components. It is necessary to conduct further research in this area on a larger population.

\section{Acknowledgments}

This study was conducted with the support of the Maria Skłodowska-Curie Institute of Oncology in Warsaw and the Polish-Norwegian Foundation Research Fund. The research data were collected within the scope of PONS research: 'Establishing infrastructure for studies concerning health state of the population of Poland' (PNRF-228-AI-1/07) (data collection). This study was supported by a grant from The Ministry of Science and Higher Education from the funds received within financing for statutory activity for the Faculty of Medicine and Health Sciences, Jan Kochanowski University, research project No. 615507 (data analysis and preparation of the manuscript).

\section{Conflict of interest}

The authors declare no conflict of interest.

\section{References}

1. Gasparotto AS, Borges DO, Zandoná MR, Ramos MJ, Meihnardt NG, Mattevi VS. Adiponectin promoter polymorphisms are predictors of lipid profile improvement after bariatric surgery. Genet Mol Biol 2017; 40: 736-42.

2. Gao L, Wu L, Zhang M, Zhao X, Cheng H, Mi J. Genderspecific association of the rs6499640 polymorphism in the FTO gene with plasma lipid levels in Chinese children. Genet Mol Biol 2018; 41: 397-402.

3. Schäffler A, Neumeier M, Herfarth H, Fürst A, Schölmerich J, Büchler C. Genomic structure of human omentin, a new adipocytokine expressed in omental adipose tissue. Biochim Biophys Acta 2005; 1732: 96-102.

4. Yang RZ, Lee MJ, Hu H, Pray J, Wu HB, Hansen BC, Shuldiner AR, Fried SK, McLenithan JC, Gong DW. Identification of omentin as a novel depot-specific adipokine in human adipose tissue: possible role in modulating insulin action. Am J Physiol Endocrinol Metab 2006; 290: E1253-61.

5. de Souza Batista CM, Yang RZ, Lee MJ, Glynn NM, Yu DZ, Pray J, Ndubuizu K, Patil S, Schwartz A, Kligman M, 
Fried SK, Gong DW, Shuldiner AR, Pollin TI, McLenithan JC. Omentin plasma levels and gene expression are decreased in obesity. Diabetes 2007; 56: 1655-61.

6. Tan BK, Adya R, Randeva HS. Omentin: a novel link between inflammation, diabesity, and cardiovascular disease. Trends Cardiovasc Med 2010; 20: 143-8.

7. Moreno-Navarrete JM, Catalán V, Ortega F, Gómez-Ambrosi J, Ricart W, Frühbeck G, Fernández-Real JM. Circulating omentin concentration increases after weight loss. Nutr Metab 2010; 7: 27.

8. Auguet T, Quintero Y, Riesco D, Morancho B, Terra X, Crescenti A, Broch M, Aguilar C, Olona M, Porras JA, Hernandez M, Sabench F, del Castillo D, Richart C. New adipokines vaspin and omentin. Circulating levels and gene expression in adipose tissue from morbidly obese women. BMC Med Genet 2011; 12: 60.

9. Pan HY, Guo L, Li Q. Changes of serum omentin-1 levels in normal subjects and in patients with impaired glucose regulation and with newly diagnosed and untreated type 2 diabetes. Diabetes Res Clin Pract 2010; 88: 29-33.

10. Wittenbecher C, Menzel J, Carstensen-Kirberg M, Biemann R, di Giuseppe R, Fritsche A, Isermann B, Herder C, Aleksandrova $\mathrm{K}$, Boeing $\mathrm{H}$, Weikert $\mathrm{C}$, Schulze MB. Omentin-1, adiponectin, and the risk of developing type 2 diabetes. Diabetes Care 2016; 39: e79-80.

11. Jialal I, Devaraj S, Kaur H, Adams-Huet B, Bremer AA. Increased chemerin and decreased omentin-1 in both adipose tissue and plasma in nascent metabolic syndrome. J Clin Endocrinol Metab 2013; 98: 514-7.

12. Buyukinan M, Atar M, Can U, Pirgon O, Guzelant A, Deniz I. The association between serum vaspin and omentin-1 levels in obese children with metabolic syndrome. Metab Syndr Relat Disord 2018; 16: met.2017.0133.

13. Vu A, Sidhom MS, Bredbeck BC, Kosmiski LA, Aquilante CL. Evaluation of the relationship between circulating omentin- 1 concentrations and components of the metabolic syndrome in adults without type 2 diabetes or cardiovascular disease. Diabetol Metab Syndr 2014; 6: 4.

14. Kilic DC, Oguz A, Uzunlulu M, Celik S, Koroglu G. Plasma omentin-1 levels are similar in nondiabetic metabolic syndrome patients and healthy subjects. J Endocrinol Metabol 2011; 1: 182-7.

15. Tan B, Adya R, Farhatullah S, Lewandowski K, O’Hare P, Lehnert H, Randeva HS. Omentin-1, a novel adipokine, is decreased in overweight insulin resistant women with the polycystic ovary syndrome: ex vivo and in vivo regulation of omentin-1 by insulin and glucose. Diabetes 2008; 57: 801-8.

16. Harada K, Shibata R, Ouchi N, Tokuda Y, Funakubo H, Suzuki M, Kataoka T, Nagao T, Okumura S, Shinoda N, Kato B, Sakai S, Kato M, Marui N, Ishii H, Amano T, Matsubara T, Murohara T. Increased expression of the adipocytokine omentin in the epicardial adipose tissue of coronary artery disease patients. Atherosclerosis 2016; 251: 299-304.

17. Schäffler A, Zeitoun M, Wobser H, Buechler C, Aslanidis $\mathrm{C}$, Herfarth $\mathrm{H}$. Frequency and significance of the novel single nucleotide missense polymorphism Val109Asp in the human gene encoding omentin in Caucasian patients with type 2 diabetes mellitus or chronic inflammatory bowel diseases. Cardiovasc Diabetol 2007; 6: 3 .

18. Isakova ZT, Talaibekova ET, Asambaeva DA, Kerimkulova AS, Lunegova OS, Aldasheva NM, Aldashev AA. A po- lymorphic marker Val109Asp in the omentin gene are associated with abdominal obesity in the Kyrgyz population. Probl Endocrinol 2016; 62: 4-8.

19. Zatoński WA, Mańczuk M; Polish-Norwegian Study (PONS). Research on chronic non-communicable diseases in European high risk countries - study design. Ann Agric Environm Med 2011; 18: 203-6.

20. Suliga E, Kozieł D, Cieśla E, Rębak D, Głuszek S. Dietary patterns in relation to metabolic syndrome among adults in Poland: a cross-sectional study. Nutrients 2017; 9: pii: E1366.

21. Alberti KG, Eckel RH, Grundy SM, Zimmet PZ, Cleeman JI, Donato KA, Fruchart JC, James WP, Loria CM, Smith SC Jr; International Diabetes Federation Task Force on Epidemiology and Prevention; Hational Heart, Lung, and Blood Institute; American Heart Association; World Heart Federation; International Atherosclerosis Society; International Association for the Study of Obesity. Harmonizing the metabolic syndrome: a joint interim statement of the International Diabetes Federation Task Force on Epidemiology and Prevention; National Heart, Lung, and Blood Institute; American Heart Association; World Heart Federation; International Atherosclerosis Society; and International Association for the Study of Obesity. Circulation 2009; 120: 1640-5.

22. International Physical Activity Questionnaire (IPAQ) The Long Form. Available online: http://www.sdp.univ. fvg.it/sites/default/files/IPAQ_English_self-admin_long. pdf (accessed on 15 March 2010).

23. Rębak D, Suliga E, Głuszek S. Metabolic syndrome and professional aptitude. Studia Medyczne 2015; 31: 286-94.

24. Urbanová M, Dostálová I, Trachta P, Drápalová J, Kaválková P. Serum concentrations and subcutaneous adipose tissue mRNA expression of omentin in morbid obesity and type 2 diabetes mellitus: the effect of very-low-calorie diet, physical activity and laparoscopic sleeve gastrectomy. Physiol Res 2014; 8408: 207-18.

25. Herder C, Kannenberg JM, Niersmann C, Huth C, Carstensen-Kirberg M, Wittenbecher C, Schulze M, Blüher M, Rathmann W, Peters A, Roden M, Meisinger C, Thorand B. Independent and opposite associations of serum levels of omentin-1 and adiponectin with increases of glycaemia and incident type 2 diabetes in an older population: KORA F4/FF4 study. Eur J Endocrinol 2017; 177: 277-86.

26. Panagiotou G, Mu L, Na B, Mukamal KJ, Mantzoros CS. Circulating irisin, omentin-1, and lipoprotein subparticles in adults at higher cardiovascular risk. Metab Clin Exp 2014; 63: 1265-71.

27. Cătoi AF, Suciu Ş, Pârvu AE, Copăescu C, Galea RF, Buzoianu AD, Vereşiu IA, Cătoi C, Pop ID. Increased chemerin and decreased omentin-1 levels in morbidly obese patients are correlated with inculin resistance, oxidative stress and chronic inflammation. Clujul Med 2014; 87: 19-26.

28. Guvenc Y, Var A, Goker A, Kuscu NK. Assessment of serum chemerin, vaspin and omentin- 1 levels in patients with polycystic ovary syndrome. J Int Med Res 2016; 44: 796-805.

29. Elsaid NH, Sadik NA, Ahmed NR, Fayez SE, Mohammed NA. Serum omentin- 1 levels in type 2 diabetic obese women in relation to glycemic control, insulin resistance and metabolic parameters. J Clin Transl Endocrinol 2018; 13: 14-9. 
30. Shibata R, Ouchi N, Takahashi R, Terakura Y, Ohashi K, Ikeda N, Higuchi A, Terasaki H, Kihara S, Murohara T. Omentin as a novel biomarker of metabolic risk factors. Diabetol Metab Syndr 2012; 4: 37.

31. Stejskal D, Vaclavik J, Smekal A, Svobodova G, Richterova $R$, Svestak M. Omentin-1 levels in patients with premature coronary artery disease, metabolic syndrome and healthy controls. Biomed Pap Med Fac Univ Palacky Olomouc Czech Repub 2016; 160: 219-21.

32. Suliga E, Wawszczak M, Gluszek S. The roles of vaspin chemerin, and omentin in the determination of metabolic syndrome. Medical Studies 2018; 34: 160-77.

33. Splichal Z, Bienertova-Vasku J, Novak J, Zlamal F, Tomandl J, Tomandlova M, Forejt M, Havlenova S, Jackowska A, Vasku A. The common polymorphism Val109Asp in the omentin gene is associated with daily energy intake in the Central-European population. Nutr Neurosci 2015; 18 : 41-8.

34. Kohan L, Safarpur M, Abdollahi H. Omentin-1 rs2274907 and resistin rs1862513 polymorphisms influence genetic susceptibility to nonalcoholic fatty liver disease. Mol Biol Res Commun 2016; 5: 11-7.

35. Askari SN, Zehra S, Azhar A. Association of single nucleotide missence polymorphism Val109Aspof omentin-1 gene and coronary artery disease in Pakistani population: multicenter study. Pak J Med Sci 2017; 33: 1128-33.

36. Yörük U, Yaykaşli KO, Özhan H, Memişoğullari R, Karabacak A, Bulur S, Aslantaş Y, Başar C, Kaya E. Association of omentin Val109Asp polymorphism with coronary artery disease. Anatolu J Cardiol 2014; 14: 511-4.

37. Jamshidi J, Ghanbari M, Asnaashari A, Jafari N, Valizadeh GA. Omentin Val109Asp polymorphism and risk of coronary artery disease. Asian Cardiovasc Thorac Ann 2017; 25: 199-203.

\section{Address for correspondence:}

Monika Wawszczak

Genetic Laboratory

Medical Sciences

Faculty of Medicine and Health Sciences

Jan Kochanowski University

al. IX Wieków Kielc 19, 25-516 Kielce, Poland

Phone: +48 503772301

E-mail:wawszczak.monika@gmail.com 